\section{Sensory and microbiological evaluation of traditional ovine ricotta cheese in modified atmosphere packaging}

\author{
Isabella Mancuso, ${ }^{1}$ Cinzia Cardamone, ${ }^{1}$ \\ Gerlando Fiorenza, ${ }^{1}$ Giusi Macaluso, ${ }^{1}$ \\ Luigi Arcuri, ${ }^{2}$ Viviana Miraglia, ${ }^{1}$ \\ Maria Luisa Scatassa' \\ 'Istituto Zooprofilattico Sperimentale \\ della Sicilia A. Mirri, Palermo; \\ 2Servizio Veterinario, Azienda Sanitaria \\ Provinciale 6, Palermo, Italy
}

\section{Abstract}

Ovine ricotta cheese is a traditional Sicilian dairy product characterised by high humidity and a short shelf life (2-4 days when refrigerated). The increasing demand for fresh food has prompted manufacturers to develop special packaging techniques, such as modified atmosphere packaging (MAP), that can extend the shelf life and maintain the organoleptic characteristics of ovine ricotta cheese. The aim of the present study was to evaluate the shelf life of fresh MAP-packed ovine ricotta cheese by monitoring the microbiological, chemical, physical and organoleptic characteristics of the product. Samples of a single batch were packed in MAP or vacuum packed and stored at $4^{\circ} \mathrm{C}$ for 24 and 7 days, respectively. Water activity, $\mathrm{pH}$, physicochemical parameters and microbiological characteristics were examined. A sensory panel rated the product's main organoleptic characteristics (colour, odour, flavour and texture). Results showed that MAP controlled the development of any unwanted microflora, but did not affect the development of intrinsic lactic floras or chemical parameters. Sensory analysis revealed that overall the MAP-packed ricotta remained acceptable for up to 15 days of storage. The vacuum-packed ricotta cheese, however, showed a progressive deterioration in organoleptic characteristics from day 5 onward and therefore had a shorter shelf life. In conclusion, the ability of MAP to extend the shelf life of a traditional regional product (such as fresh ovine ricotta cheese) guarantees consumers a quality product and provides opportunities for manufacturers to expand their markets beyond national boundaries.

\section{Introduction}

Ricotta cheese is a traditional dairy product of some Italian regions, obtained from the thermo-acid coagulation of proteins in the residual whey of processed ovine or bovine cheese. Ricotta (literally twice cooked) is produced by first heating milk at $37^{\circ} \mathrm{C}$ to produce cheese and then treating the whey thermally at $80-90^{\circ} \mathrm{C}$ (Gammariello et al., 2009). This thermal treatment results in the denaturation of residual proteins, mainly albumin and globulin, which, when surfacing, retain the fat globules remaining from the cheese processing. During the production of Sicilian ovine ricotta cheese, the whey is enriched with whole raw ovine milk (5-15\%) to increase the yield and improve the commercial characteristics of the product. Most importantly, it should be noted that for the purposes of the present study the term cheese for a dairy product obtained by coagulation of whey proteins is used in a conscious manner and without ambiguity.

When properly refrigerated, ricotta generally has a shelf life of only a few days because of its high moisture level and $\mathrm{pH}$ (above 6). To meet the commercial needs of medium and large distribution and still maintain the typical sensorial characteristics of the traditional product, it is necessary to extend the product's shelf life.

Modified atmosphere packaging (MAP) improves the shelf life of fresh food and dairy products such as: provolone cheese, ricotta, Apulian fresh cheese and Lor whey cheese (Gonzales-Fondos et al., 2000; Del Nobile et al., 2009; Gammariello et al., 2009; Irkin, 2011). Few studies about MAP ovine ricotta cheese are available in the literature (Del Nobile $e t$ al., 2009). $\mathrm{CO}_{2}$ has bacteriostatic and fungistatic effects, especially on Gram-negative, aerobic, psychrotrophic bacteria (Daniels et al., 1985), although high concentrations of $\mathrm{CO}_{2}$ may influence the organoleptic characteristics (Gonzales-Fondos et al., 2000; Favati et al., 2007).

The aim of the present study was to evaluate the shelf life of MAP-packed ricotta ovine cheese by monitoring microbial, physicochemical, and sensory parameters of the cheese during its storage period.

\section{Materials and Methods}

This study was conducted on a batch of Sicilian ovine ricotta cheese produced on a dairy farm in the province of Enna. The ricotta cheese was produced according to the traditional process, using the whey of ovine milk from Pecorino cheese processing and adding $13.5 \%$ raw sheep's milk. The MAP-packed ricotta cheese (MAP ricotta) was portioned into 500 -g packages using a gas mixture consisting of $30 \% \mathrm{CO}_{2}$ and $70 \% \mathrm{~N}_{2}$. Some of the ricotta cheese was vacuum packed (VP) ricotta to be compared with the MAP ricotta. Packages con-
Correspondence: Maria Luisa Scatassa, Istituto Zooprofilattico Sperimentale della Sicilia A. Mirri, via Gino Marinuzzi 3, 90129 Palermo, Italy. Tel. +39.091.6565300 - Fax: +39.091 .6565332$

E-mail: luisa.scatassa@izssicilia.it

Key words: MAP, Ricotta cheese, Shelf life, Sensory parameters.

Conflict of interests: the authors declare no potential conflict of interests.

Acknowledgments: this work was granted by the Italian Ministry of Health funding research project Setting up of biocompetition and decontamination methods to improve technological processes and food safety. We thank Drs. A. Carrozzo and B. Ducato for their precious collaboration.

Received for publication: 16 May 2013.

Revision received: 27 November 2013.

Accepted for publication: 12 December 2013.

This work is licensed under a Creative Commons Attribution 3.0 License (by-nc 3.0).

(c) Copyright I. Mancuso et al., 2014

Licensee PAGEPress, Italy

Italian Journal of Food Safety 2014; 3:1725

doi:10.4081/ijfs.2014.1725

sisted of two plastic cylindrical containers placed one inside the other; the inner container was pierced to allow the ricotta to drain. For the first $3 \mathrm{~h}$ after production the samples were left to drain at room temperature, then they were stored at $4^{\circ} \mathrm{C}$ overnight. After packing, they were refrigerated and sent to the Centro Latte e Lotta alle Mastiti laboratory of the Istituto Zooprofilattico Sperimentale della Sicilia, Palermo, Southern Italy. Laboratory analysis and sensory evaluations were performed on the MAP ricotta $24 \mathrm{~h}$ after production (T1) and at successive intervals up to 24 days (T3, T7, T11, T14, T17, T21 and T24). The VP ricotta was analysed at $\mathrm{T} 1, \mathrm{~T} 3$ and $\mathrm{T} 7$ (the end of its shelf life). Furthermore, to mimic domestic storage conditions, part of the MAP ricotta was stored at $7 \pm 1^{\circ} \mathrm{C}$.

All the samples were analysed for water activity (ISO 21807:2004; ISO, 2004), pH (DocuMeter Sartorius; Data Weighing Systems, Inc., Elk Grove, IL, USA) and microbiological analyses: total bacterial count (TBC) at $30^{\circ} \mathrm{C}$ (ISO $4833: 2003$; ISO, 2003b), total coliforms (ISO 4832:2006; ISO, 2006), enterococci (on Rapid Enterococcus agar, at $44^{\circ} \mathrm{C}$ for 48 h), coagulase-positive staphylococci (ISO 6888-2:1999 Amend 1:2003; ISO, 2003a), Escherichia coli (IS0 16649-2:2010; UNI, 2010), Salmonella spp. (AOAC 120301:2003) and Listeria monocytogenes (AOAC 070401:2004) (AOAC, 2004). Lactic acid bacteria (LAB) were isolated and enumerated using the ISTISAN $08 / 36$; they were identified by 
sequencing a 350 -bp region within bacterial 16S rRNA using the primers ITS F (5'-GTC GTA ACA AGG TAG CCG TA-3') and ITS R (5'-GCC AAG GCA TCC ACC-3') (White et al., 1990). DNA sequences were determined by using an ABI PRISM 3130 Genetic Analyzer (Applied Biosystems, Carlsbad, CA, USA) and compared using a BLAST search in the GenBank/EMBL/ DDBJ database. Commodity-related parameters, such as fat, protein, salt, moisture and total solids, were determined using indirect near infrared transmittance employing the FoodScan analyser (Foss, Hillerød, Denmark).

Ricotta cheese samples were subjected to sensory evaluation by 12 judges ( 5 men and 7 women) aged 30 to 52 . The panelists evaluated the main organoleptic characteristics: colour (white, ivory, yellowish), smell (lactic, acid, ani$\mathrm{mal} /$ stable), taste (sweet, acid, salty, bitter) and consistency (creamy, pasty, grainy, unctuous). After tasting the sample, each panelist rated the overall acceptability of the product (good, acceptable, not acceptable). The samples, which were identified by number in order to avoid affecting the panel's judgements, were tasted about $30 \mathrm{~min}$ after the package had been opened and were kept at room temperature.

\section{Results}

The results of the microbiological analysis of the MAP ricotta stored at $4 \pm 1^{\circ} \mathrm{C}$ (Table 1) showed an increase in TBC from $10^{3}$ to $10^{6}$ $\mathrm{cfu} / \mathrm{g}$, from the third day of storage; this value remained constant for the duration of the observation period, settling around $10^{7} \mathrm{cfu} / \mathrm{g}$. A single aliquot at T11 showed the presence of coliforms in concentration of $10^{3} \mathrm{cfu} / \mathrm{g}$. The isolated lactic microflora was mainly represented by mesophilic cocci, which increased to $10^{5} \mathrm{cfu} / \mathrm{g}$ in the first 7 days and then remained constant. Thermophilic cocci and mesophilic rods were absent in the first two samples (T1 and T3) and from T7 their mean concentrations stabilised around $10^{3} \mathrm{cfu} / \mathrm{g}$ (Table 1). On Gram-positive and catalase- and oxidase-negative isolates, the genotyping PCR detected a predominance of Lactobacillus casei and Enterococcus faecalis and a low prevalence of Enterococcus gallinarum. $\mathrm{pH}$ and $\mathrm{a}_{\mathrm{w}}$ values are shown in Table 2 ; specifically $\mathrm{a}_{\mathrm{w}}$ remained constant and decreased slightly from T17, with values ranging from 0.97 to 0.94 , whereas $\mathrm{pH}$ decreased from 6.54 to 5.96 . The main commodity-related parameters (Table 2) reflect those commonly found in ovine ricotta cheese. The MAP ricotta samples stored at $7 \pm 1^{\circ} \mathrm{C}$ did not differ from those kept at $4^{\circ} \mathrm{C}$ in terms of microbiological characteristics (Table 3) and sensory evaluation.

The results of the microbiological analysis of the VP ricotta were similar to those of the
MAP ricotta; TBC ranged from $6.7 \times 10^{3} \mathrm{cfu} / \mathrm{g}$ (T1) to $8.8 \times 10^{6} \mathrm{cfu} / \mathrm{g}$ (T7) and the values of final $\mathrm{pH}$ and $\mathrm{a}_{\mathrm{w}}$ (T7) were 6.36 and 0.96 , respectively. The only difference is that lactic microfloras were present in lower concentrations: mesophilic cocci were only isolated in concentrations from 1.0 (T1) to $7.2 \times 10^{2} \mathrm{cfu} / \mathrm{g}$ (T7).

No pathogens (e.g. Listeria monocytogenes, Salmonella spp.), coagulase-positive staphylococci or $E$. coli were detected in any of the samples examined.

Sensory evaluation of the MAP ricotta showed that the sample was white at T1 only, ivory up to T17 and yellowish up to T24. The

smell was classified as predominantly lactic up to T14; from T17 most of the evaluators perceived acidic notes that became more intense and were noted by everyone at T21 and T24. The taste was pleasant, sweet, slightly acidic or salty up to T14, then salty, salty-bitter and markedly acidic at T24. The consistence was creamy, grainy and slightly unctuous until T3, but then it became pasty and more unctuous from T7 to T24.

From T11 onwards, whey was found at the bottom of the perforated trays and the quantity increased in the following days as a result of incipient separation of the liquid and solid components.

Table 1. Microbiological parameters of modified atmosphere-packed ricotta cheese stored at $4^{\circ} \mathrm{C}$.

\begin{tabular}{|c|c|c|c|c|c|}
\hline $\begin{array}{l}\text { Storage } \\
\text { time }\end{array}$ & $\begin{array}{c}\mathrm{TBC} \\
\text { at } 30^{\circ} \mathrm{C}\end{array}$ & Coliforms & $\begin{array}{c}\text { Thermophilic } \\
\text { cocci }\end{array}$ & $\begin{array}{l}\text { Mesophilic } \\
\text { cocci }\end{array}$ & $\begin{array}{l}\text { Mesophilic } \\
\text { rods }\end{array}$ \\
\hline $\mathrm{Tl}$ & $6.7 \times 10^{3}$ & $<1$ & $<1 \times 10^{1}$ & $1.0 \times 10^{2}$ & $<1 \times 10^{1}$ \\
\hline T3 & $1.5 \times 10^{6}$ & $<1$ & $<1 \times 10^{1}$ & $7.2 \times 10^{4}$ & $<1 \times 10^{1}$ \\
\hline T7 & $1.2 \times 10^{7}$ & $<1$ & $1.6 \times 10^{3}$ & $1.0 \times 10^{5}$ & $3.5 \times 10^{3}$ \\
\hline T11 & $2.8 \times 10^{7}$ & $1.3 \times 10^{3}$ & $1.5 \times 10^{3}$ & $1.7 \times 10^{5}$ & $4.1 \times 10^{3}$ \\
\hline T14 & $5.5 \times 10^{7}$ & $<1$ & $1.6 \times 10^{3}$ & $3.4 \times 10^{6}$ & $6.9 \times 10^{3}$ \\
\hline $\mathrm{T} 17$ & $4.5 \times 10^{7}$ & $<1$ & $1.1 \times 10^{3}$ & $2.1 \times 10^{5}$ & $5.8 \times 10^{3}$ \\
\hline $\mathrm{T} 21$ & $4.1 \times 10^{7}$ & $<1$ & nd & nd & nd \\
\hline $\mathrm{T} 24$ & $3.6 \times 10^{7}$ & $<1$ & nd & nd & nd \\
\hline
\end{tabular}

TBC, total bacterial count; nd, not determined. Values are expressed as cfu/g.

Table 2. $\mathrm{a}_{\mathrm{w}}, \mathrm{pH}$ values and commodity-related parameters of modified atmosphere-packed ricotta cheese stored at $4^{\circ} \mathrm{C}$.

\begin{tabular}{lccccccc} 
Storage time & $\mathrm{a}_{\mathrm{w}}$ & $\mathrm{pH}$ & Fat $^{\circ}$ & Protein $^{\circ}$ & Salt $^{\circ}$ & Moisture $^{\circ}$ & Total solids $^{\circ}$ \\
T1 & 0.97 & 6.54 & 11.67 & 8.64 & 0.90 & 75.24 & 24.76 \\
T3 & 0.96 & 6.39 & 12.65 & 9.24 & 0.95 & 74.07 & 25.93 \\
T7 & 0.96 & 6.37 & 13.13 & 8.71 & 1.05 & 74.31 & 25.69 \\
T11 & 0.97 & 6.15 & 11.27 & 8.93 & 1.04 & 74.77 & 25.23 \\
T14 & 0.96 & 5.97 & 13.63 & 8.69 & 1.20 & 73.07 & 27.04 \\
T17 & 0.95 & 5.97 & 12.99 & 8.51 & 1.17 & 73.60 & 26.40 \\
\hline T21 & 0.95 & 5.97 & nd & nd & nd & nd & nd \\
T24 & 0.94 & 5.96 & nd & nd & nd & nd & nd \\
\hline
\end{tabular}

$\mathrm{A}_{\mathrm{w}}$, water activity; nd, not determined. ${ }^{\circ}$ Values are expressed as $\mathrm{g} / 100 \mathrm{~g}$.

Table 3. Microbiological parameters of modified atmosphere-packed ricotta cheese stored at $7^{\circ} \mathrm{C}$.

\begin{tabular}{lccccc}
$\begin{array}{l}\text { Storage } \\
\text { time }\end{array}$ & $\begin{array}{c}\text { TBBC } \\
\text { at } 30^{\circ} \mathrm{C}\end{array}$ & $\begin{array}{c}\text { Coliforms } \\
\text { T1 }\end{array}$ & $\begin{array}{c}\text { Thermophilic } \\
\text { cocci }\end{array}$ & $\begin{array}{c}\text { Mesophilic } \\
\text { cocci }\end{array}$ & $\begin{array}{c}\text { Mesophilic } \\
\text { rods }\end{array}$ \\
T3 & $1.4 \times 10^{3}$ & $<1$ & $<1 \times 10^{6}$ & $2.3 \times 10^{2}$ & $<1 \times 10^{1}$ \\
T7 & $9.8 \times 10^{6}$ & $<1$ & $<1 \times 10^{1}$ & $6.8 \times 10^{4}$ & $<1 \times 10^{1}$ \\
T11 & $2.9 \times 10^{7}$ & $<1$ & $9.7 \times 10^{2}$ & $1.3 \times 10^{5}$ & $5.5 \times 10^{3}$ \\
T14 & $4.6 \times 10^{7}$ & $<1$ & $1.6 \times 10^{3}$ & $1.5 \times 10^{5}$ & $5.1 \times 10^{3}$ \\
T17 & $4.2 \times 10^{7}$ & $<1$ & $1.4 \times 10^{3}$ & $3.1 \times 10^{6}$ & $6.5 \times 10^{3}$ \\
T21 & $5.2 \times 10^{7}$ & $<1$ & nd & $3.3 \times 10^{6}$ & $6.8 \times 10^{3}$ \\
T24 & $9.5 \times 10^{7}$ & $<1$ & nd & nd & nd \\
\hline
\end{tabular}

TBC, total bacterial count; nd, not determined. Values are expressed as cfu/g. 
The VP ricotta was ivory up to T3, had a lactic odour, a sweet or slightly salty taste, and a creamy or slightly grainy consistency; almost all tasters considered it good. At T7 the majority of the panelists changed their taste rating from sweet to acidic and bitter; the consistency was rated as pasty and unctuous; and the pleasantness rating was good for three subjects, acceptable for four and not acceptable for five. Sensory evaluation of MAP ricotta cheese showed that the pleasantness judgment was evaluated as good for most of the tasters until T3 and always as acceptable overall up to T14, with the exception of two evaluators who defined the T11 ricotta cheese as not acceptable. At 17 days of storage 7/12 tasters evaluated the MAP samples as acceptable, while at T24 the unanimous opinion was not acceptable. For VP ricotta the pleasantness assessment appeared better (good) up to T3, while at T7 $5 / 12$ evaluators defined it as not accettable.

\section{Discussion}

The literature reports different findings about the effect of $\mathrm{CO}_{2}$ on the growth of lactic acid bacteria, due to their microaerophilic nature. Our results showed increased concentrations of rod- and bacillus-shaped lactic flora after a lag phase of 3-7 days, together with a decrease in $\mathrm{pH}$, as reported by Del Nobile et al. (2009) and Irkin (2011). According to Irkin (2011), vacuum packaging gives lower counts than MAP. Total bacterial count up to T7 in MAP and VP ricotta were similar; Irkin (2011) reports an increase of TBC in VP whey cheese after ten days of storage, a period that we did not investigate because the deterioration in the sensory characteristics made the VP ricotta cheese unacceptable.

The values of $\mathrm{pH}$ and $\mathrm{a}_{\mathrm{w}}$ we observed to promote the growth of lactic acid bacteria; our results of the physicochemical analysis were similar to those detected in Sardinian ovine ricotta cheese (Scintu et al., 2001). Sensory evaluation of MAP ricotta cheese produced overall judgments of acceptable up to T14. The 2/12 evaluators who considered the T11 ricotta cheese to be unacceptable were probably more sensitive to the presence of coliforms detected in this sample, resulting from the probable contamination of the aliquot during the packaging phase. The presence of whey in the bottom of the perforated trays from day 11 is considered to be a defect by Sicilian consumers who are used to the fresh product, although it did not affect the sensory characteristics. The VP ricotta cheese at T3 was more popular, while at T7 most of the evaluators preferred the MAP product.

\section{Conclusions}

Overall, the ricotta cheese samples tested showed normal microbiological characteristics with a good lactic microflora content that remained almost constant for the entire observation period.

Modified atmosphere packaging of traditional Sicilian ovine ricotta cheese preserved the typical organoleptic characteristics of this product for up to 15 days, twice the shelf life of the vacuum-packed product, thus allowing producers to access markets which are further away and even abroad. Since traditional ricotta cheese is highly perishable, if manufacturers want to guarantee a shelf life of 15 days they must ensure high standards of hygiene during the production process and maintain the cold chain during distribution and marketing phases. The gas mixture used $\left(30 \% \mathrm{CO}_{2}\right.$ and $70 \% \mathrm{~N}_{2}$ ) ensured that good sensory characteristics were maintained, but it was unable to inhibit the viability of coliforms, if any. However, further work is necessary to establish the optimum gas concentration for packaging this product, in order to ensure an extended shelf life, the inhibition of undesirable microorganisms and the conservation of sensorial attributes.

\section{References}

A0AC, 2004. Official methods of analysis. 17th ed., Association of Official Analytical Chemists, Gaithersburg, MD, USA.

Daniels JA, Krishnamurthi R, Rizvi SSH, 1985. A review of effect of carbon dioxide on microbial growth and food quality. J Food Protect 48:532-7.

Del Nobile MA, Conte A, Incoronato AL, Panza 0, 2009. Modified atmosphere packaging to improve the microbial stability of ricotta. Afr J Microbiol Res 3:137-42.

Favati F, Galgano F, Pace AM, 2007. Shelf life evaluation of portioned Provolone cheese packaged in protective atmosphere. LWTFood Sci Technol 40:480-8.

Gammariello D, Conte A, Attanasio M, Del Nobile MA, 2009. Effect of modified atmos- pheres on microbiological and sensorial properties of Apulian fresh cheeses. Afr J Microbiol Res 3:370-8.

Gonzalez-Fondos E, Sanz S, Olarte C, 2000. Microbiological physicochemical and sensory characteristics of Cameros cheese packaged under modified atmospheres. Food Microbiol 17:407-14.

Irkin R, 2011. Shelf life of unsalted and light "Lor" whey cheese stored under various packaging conditions: microbiological and sensory attributes. J Food Process Pres 35:163-78.

ISO, 2003a. Microbiology of food and animal feeding stuffs. Horizontal method for the enumeration of coagulase-positive staphylococci (Staphylococcus aureus and other species). Part 2: Technique using rabbit plasma fibrinogen agar medium. Including amendment 1 2003. ISO norm 68882:1999/Amend 1:2003. International Standardization Organization ed., Geneva, Switzerland.

ISO, 2003b. Microbiology of food and animal feeding stuffs. Horizontal method for the enumeration of microorganisms. Colonycount technique at 30 degrees $\mathrm{C}$. ISO norm 4833:2003. International Standardization Organization ed., Geneva, Switzerland.

ISO, 2006. Microbiology of food and animal feeding stuffs. Horizontal method for the enumeration of coliforms. Colony-count technique. ISO norm 4832:2006. International Standardization Organization ed., Geneva, Switzerland.

Scintu MF, Pirisi A, Piredda G, Deriu A, Riu G, Pes M, 2001. [Caratteristiche microbiologiche e fisico-chimiche della ricotta ovina fresca prodotta in Sardegna]. [Article in Italian]. Available from: http://web.tiscali.it/antonio.pirisi/20012010-2.html

UNI, 2010. UNI, 2001. UNI 16649-2:2010 norm. [Microbiologia di alimenti e mangimi per animali - Metodo orizzontale per la conta di Escherichia coli beta glucuronidasipositiva - Parte 2: Tecnica della conta delle colonie a $44{ }^{\circ} \mathrm{C}$ che utilizza 5 -bromo-4cloro-3- indolil beta-D-glucuronide]. [Regulation in Italian]. Italian Unification Institute ed., Milan, Italy.

White TJ, Bruns T, Lee S, Taylor JW, 1990. Amplification and direct sequencing of ribosomal RNA genes for phylogenetics. In: Innis MA, Gelfand DH, Sninsky JJ, White TJ, eds. PCR protocols: a guide to methods and applications. Academic Press, New York, NY, pp 315-22. 